\title{
ЗВІТ НАЦІОНАЛЬНОЇ АКАДЕМІЇ ПЕДАГОГІЧНИХ НАУК УКРАЇНИ ПРО СТАН ВИКОРИСТАННЯ КОШТІВ НА НАУКОВУ I НАУКОВО-ТЕХНІЧНУ ДІЯЛЬНІСТЬ ТА ОТРИМАНІ РЕЗУЛЬТАТИ ЗА 2020 р.
}

\author{
Наукова доповідь на засіданні робочої групи Начіональної ради України з \\ питань розвитку науки і технологій 16 червня 2021 р., м. Київ, Україна
}

https://doi.org/10.37472/2707-305X-2021-3-1-3-7

\section{KPEMEHb}

\section{Василь Григорович}

доктор філософьських наук, профресор, дійсний член (академік) НАН України і НАПН України, президент Національної академії педагогічних наук України, м. Київ, Україна

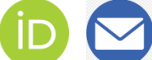

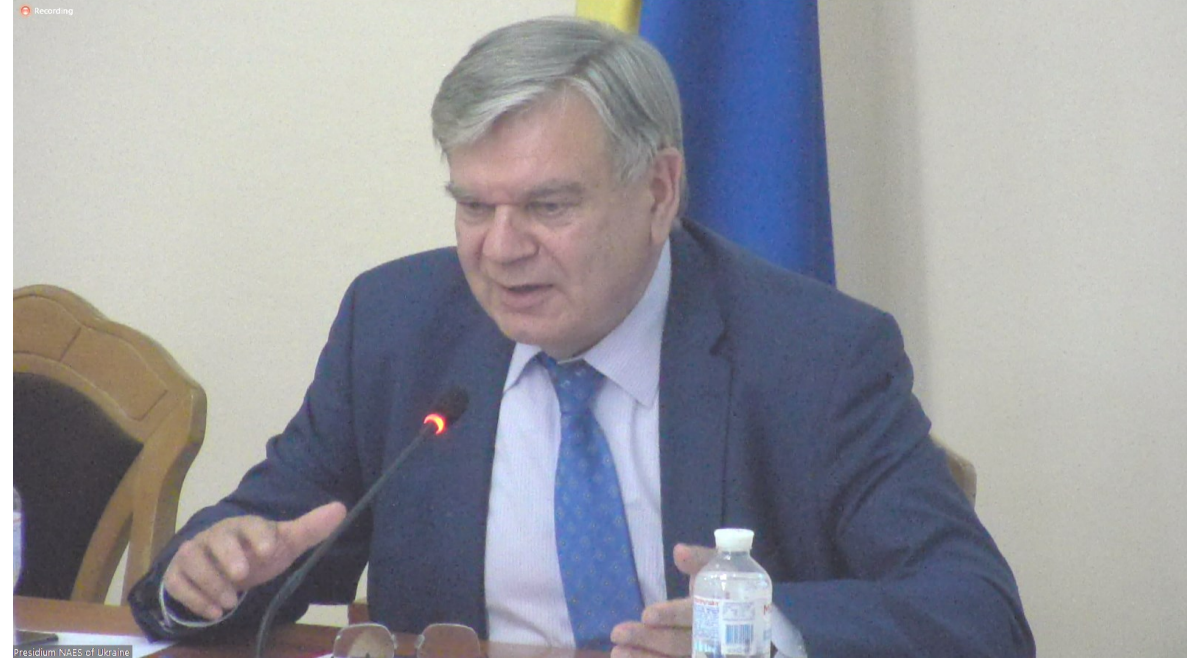

Анотація. У доповіді висвітлено результати наукової діяльності Національної академії педагогічних наук України у 2020 р., ї підвідомчих установ, розвитку кадрового потенціалу. Представлено найванливіші досягнення вчених НАПН України у науковому і методичному забезпеченні дошкільної, повної загальної середньої, професійної (професійно-технічної), фрахової передвищої, вищої освіти і освіти дорослих, освіти дітей з різними порушеннями розвитку та переходу до інклюзивного навчання, иифровізаиії освіти та дистанційного навчання, психологічної підтримки розвитку особистості, зокрема в умовах складних сочіальних обставин, розвитку психологічної служби системи освіти в процесі децентралізації. Наведено вагомі здобутки дослідників НАПН України за результатами грантових проєктів Національного фонду досліджень України та у межах виконання міжнародних проєктів. Зазначено основні показники діяльності у 2020 р. щодо наукових публікацій вчених, зокрема істотного зростання кількості праць у наукометричних базах даних Web of Science i Scopus, формування i використання ресурсу Електронної бібліотеки НАПН України, підвищення якості наукових періодичних видань, співпраці з органами державної влади, організаціями, установами, закладами, розширення експертної та експериментальної діяльності, підготовки здобувачів наукових ступенів доктора філософії і доктора наук, діяльності спеціалізованих вчених рад, роботи з молодими вченими, міннародної співпраці, науково-практичних масових заходів тощо. Привернуто увагу до нерозв'язаних проблем та окреслено перспективи розвитку академії. Наголошено на спроможності вчених НАПН України комплексно вирішувати актуальні проблеми розвитку освіти та людини в ній, забезпечувати системне і планове проведення наукових досліджень у галузі освіти, педагогіки і психології.

Ключові слова: Начіональна академія педагогічних наук України; наукова діяльність; освіта України; педагогіка; психологія; науковий і методичний супровід; розвиток інноваційної людини; людський потенціал. 
За законодавством НАПН України здійснює наукове і методичне забезпечення освітньої сфери, дослідницьку діяльність у галузі освіти, педагогіки і психології, підготовку і підвищення кваліфікації освітянських кадрів з метою розвитку національної сфери освіти, людського потенціалу країни.

Сьогодні у цій найбільшій гуманітарній сфері функціонує 33 тис. закладів, навчається 7 млн здобувачів освіти, зайнято 1,3 млн освітян.

Академія утворена Указом глави держави у 1992 р., статус національної їй надано Указом Президента України у 2010 р.

Основні завдання і функції НАПН України визначено законами, указами, іншими актами законодавства та статутом, зокрема законами України «Про наукову і науково-технічну діяльність» (2015 р.) та «Про освіту» (2017 р.).

Нині НАПН України об'єднує 10 наукових інститутів, а також Український науковометодичний центр практичної психології і соціальної роботи, Університет менеджменту освіти та Державну науково-педагогічну бібліотеку України імені В.О. Сухомлинського.

Середньооблікова чисельність штатних наукових та науково-педагогічних працівників академії в еквіваленті повної зайнятості становить 796 осіб, з них 567 (71,2 \%, у 2019 р. 70,4 \%) з науковими ступенями, зокрема докторів наук - 169 (21,2 \%). 3-поміж академіків і членів-кореспондентів три чверті представляють зовнішні заклади, установи, організації освітньо-наукового простору всієї України. Зокрема, необхідність ефективної координації їх діяльності і масштабність основних ланок освіти та їх представництва в академії, зумовлюють чинні структуру і склад ії п’яти відділень.

У цьому році 12 підвідомчих установ НАПН України успішно пройшли атестацію: 10 установ отримали I категорію, дві - II категорію. За результатами атестації будуть прийматися рішення щодо модернізації академії, реформування її установ.

Академія посилила роботу 3 молодими вченими. У 2020 р. ними виконано сім прикладних наукових досліджень.

У звітному році збільшена частка прикладних досліджень, тепер вони домінують у загальній науковій тематиці. За рахунок загального фонду бюджету виконувалося 60 прикладних і 43 фундаментальних дослідження.
Крім того, у 2020 р. три прикладних дослідження проводилися за рахунок спеціального фонду, що фінансувалися за ґрантами Національного фонду досліджень України.

Також виконувалося чотири міжнародні проєкти за ґрантовими угодами за програмою Європейського Союзу «Еразмус+». За проєктом «Відродження переміщених університетів: посилення конкурентоспроможності, підтримка громад» вартістю 1,5 млн євро Інститут вищої освіти академії є ґрантоутримувачем.

За результатами досліджень видано понад 3 тис. праць. Зокрема це - 128 монографій, 35 підручників, 202 навчальні програми і посібники, 66 методичних посібників і рекомендацій, 6 словників і довідників, 455 збірників наукових праць, 1,7 тис. статей у фахових виданнях та більше 500 інших видів видавничої продукції.

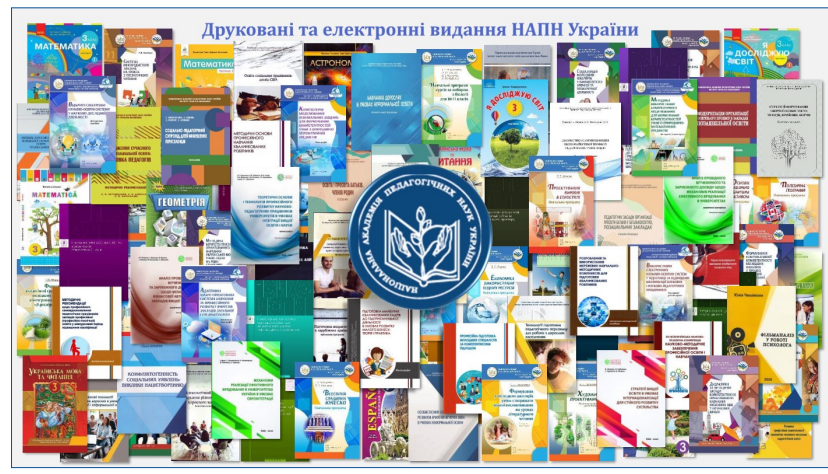

Загалом створено 159 методик, програм, концепцій, моделей. Отримано 75 свідоцтв на реєстрацію авторського права на твір.

Наукові результати завершених у 2020 р. фундаментальних та прикладних наукових досліджень використано у підготовці понад 90 законодавчих та нормативно-правових документів з питань регулювання державної освітньої політики, а також в 140 рекомендаціях міжнародних, всеукраїнських та інших науково-практичних заходів.

За звітний рік академія подвоїла кількість публікацій (323) у виданнях, що індексуються базами Web of Science Core Collection та/або Scopus. Подвоїлась і кількість (230) вчених, які мають такі публікації.

Найважливіші здобутки за 2020 р. зазначено у звітній анкеті. Назву лише окремі з них.

1. Розроблено інноваційну Концепцію освіти дітей раннього та дошкільного віку та оновлено Базовий компонент (державний стандарт) дошкільної освіти. 


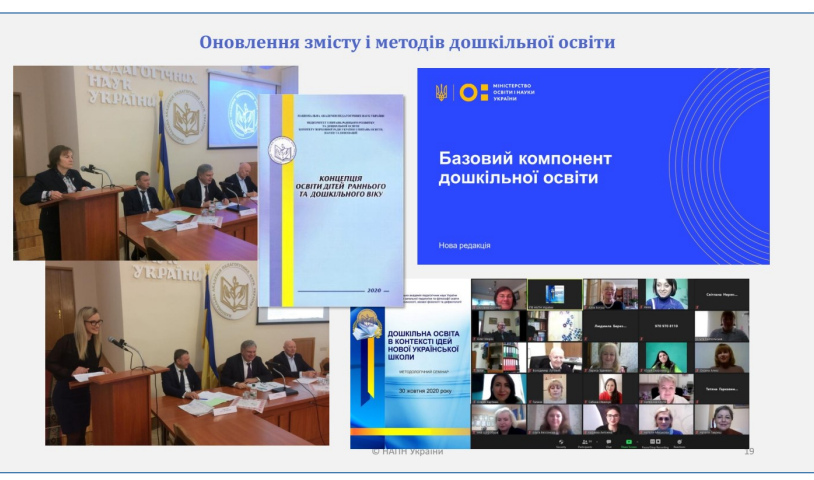

2. Сформовано науково-методичне і дидактичне забезпечення освітньої програми для 34 класів, розробленої під керівництвом академіка О.Я. Савченко, за якою працює понад $50 \%$ початкових шкіл України: створено й опубліковано 14 нових підручників для 3 класу 3 мов, математики, інтегрованого курсу «Я досліджую світ», у яких реалізовано новий зміст освіти та інноваційні підходи до його вивчення, видано методичні посібники з організації освітнього процесу в початковій школі згідно з Концепцією «Нова українська школа».

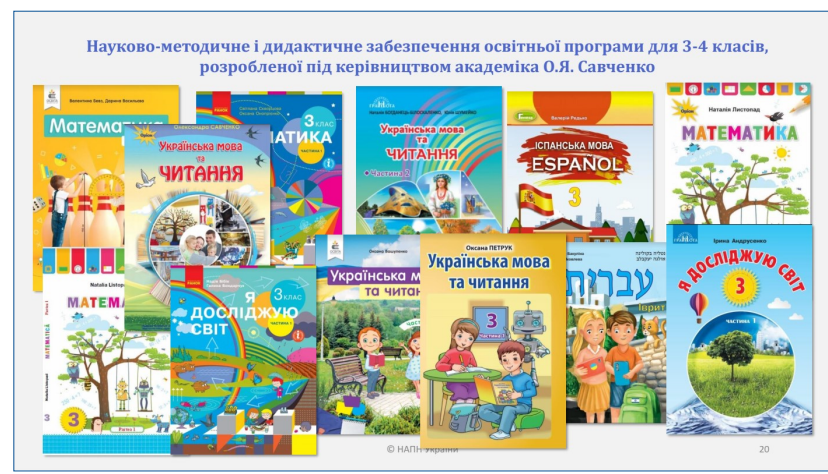

3. Розроблено новий зміст і концептуальні засади базової частини Нової української школи, що знайшло втілення в оновленому Державному стандарті базової середньої освіти та інноваційних методиках компетентнісно орієнтованого навчання української мови, української літератури, окремих мов національних меншин, математики, історії, на основі яких ученими академії створено 23 нових підручників з різних предметів,

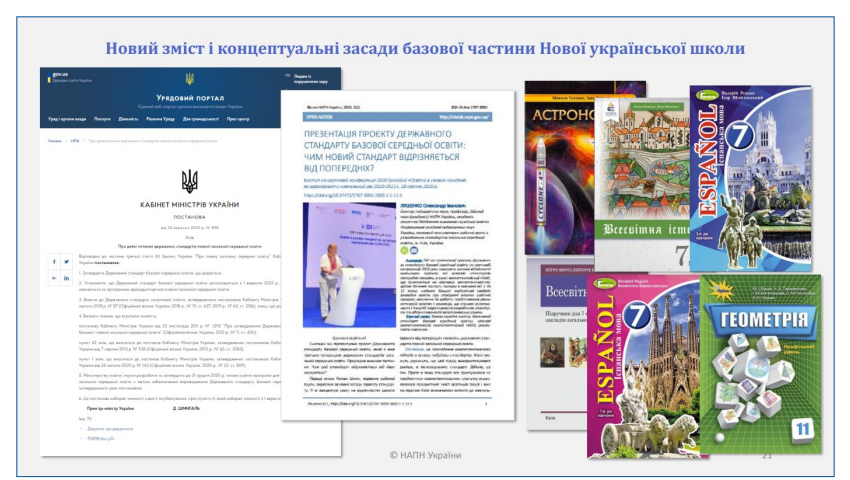

що за результатами Всеукраїнського конкурсу і вибору педагогів отримали державне фінансування, видані масовим тиражем і використовуються в освітній практиці.

4. Забезпечено подальшу цифровізацію освіти та дистанційного навчання, розроблено архітектуру і складники адаптивної інтелектуальної інформаційної системи навчання; створено програмні засоби, що реалізують функції персоналізованого інтелектуального тьютора; обґрунтовано моделі адаптивного хмаро орієнтованого навчання і професійного розвитку вчителів, а також концептуальну модель комп'ютерного моделювання для формування компетентностей учнів з природничо-математичних предметів; розроблено й розміщено в мережі Інтернет низку навчальних і методичних матеріалів для дистанційного і змішаного навчання, зокрема в умовах пандемії COVID-19.

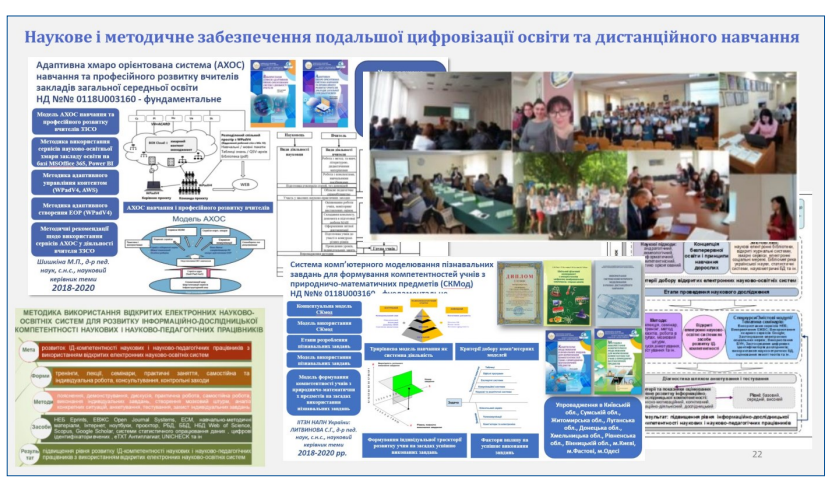

5. Розроблено навчально-методичне забезпечення переходу освіти дітей 3 особливими освітніми потребами до інклюзивного навчання, зокрема для дітей з порушеннями когнітивного розвитку; визначено основні напрями модернізації змісту освіти незрячих дітей та з порушеннями зору, обґрунтовано принципи побудови діагностичних методик для цієї категорії дітей.

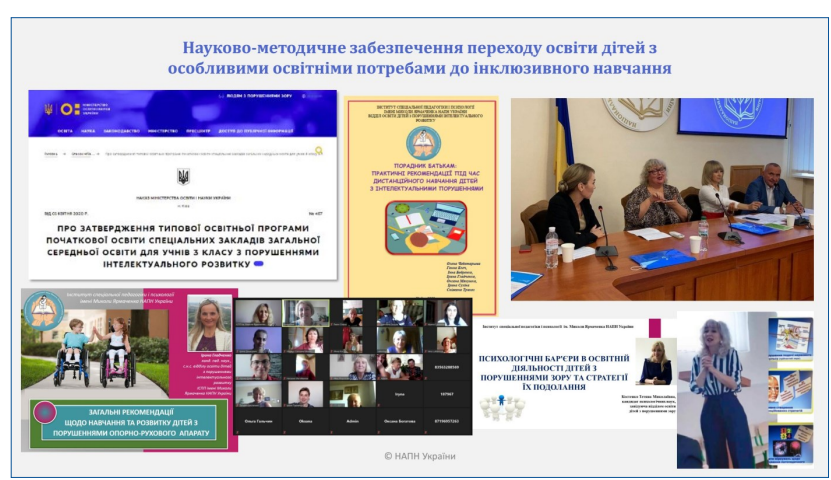

6. Розроблено концепції проєктування і створення SMART-комплексів для закладів професійної (професійно-технічної) освіти 


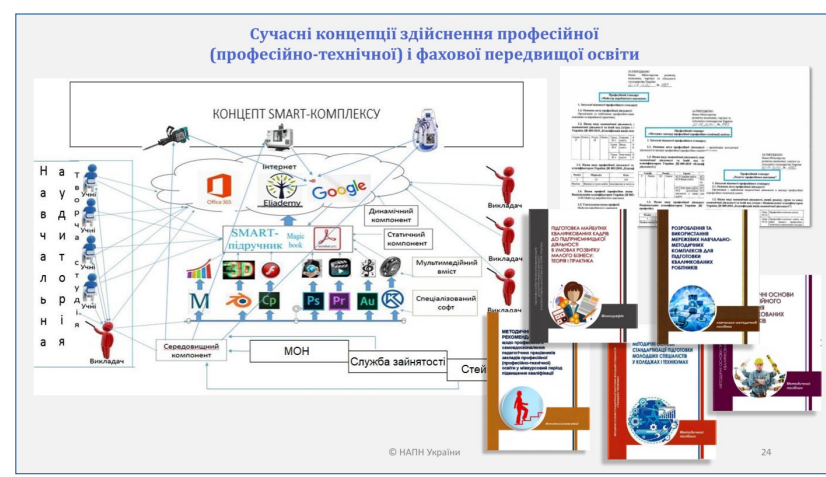

аграрної, будівельної та машинобудівної галузей; проєктування освітньо-виробничого середовища в умовах дуальної форми навчання; оцінювання якості підготовки фахівців у закладах фахової передвищої освіти; підготовки майбутніх кваліфікованих кадрів до підприємницької діяльності.

7. Обґрунтовано стратегії вищої освіти в умовах інтернаціоналізації; розроблено підходи, показники і критерії для оцінювання діяльності університетів України, запропоновано систему механізмів оцінювання освітньої якості, а також механізми розширення фінансової автономії закладів вищої освіти. Зазначені дослідницькі результати використані при підготовці проєкту Стратегії розвитку вищої освіти в Україні на 20212031 роки, що розробляється відповідно до Указу Президента України від 3 червня 2020 р. № 210.

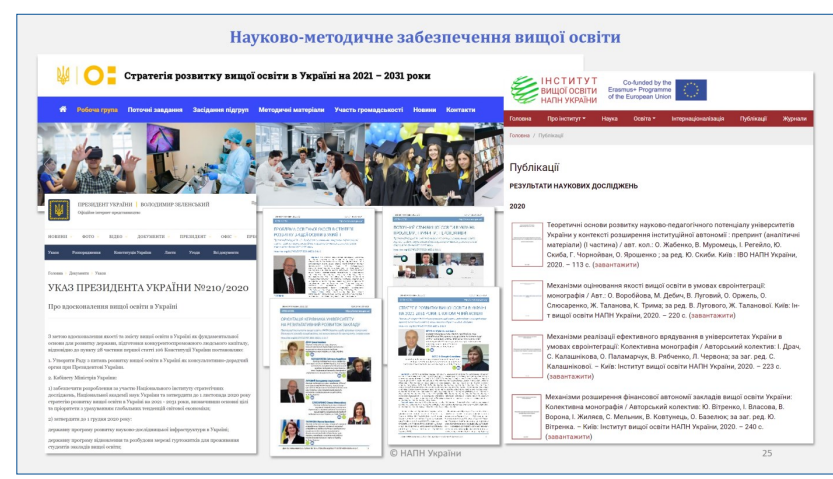

8. Розроблено спільно з МОН України проєкт Закону України «Про освіту дорослих», а також навчальну програму курсу «Професійна компетент-

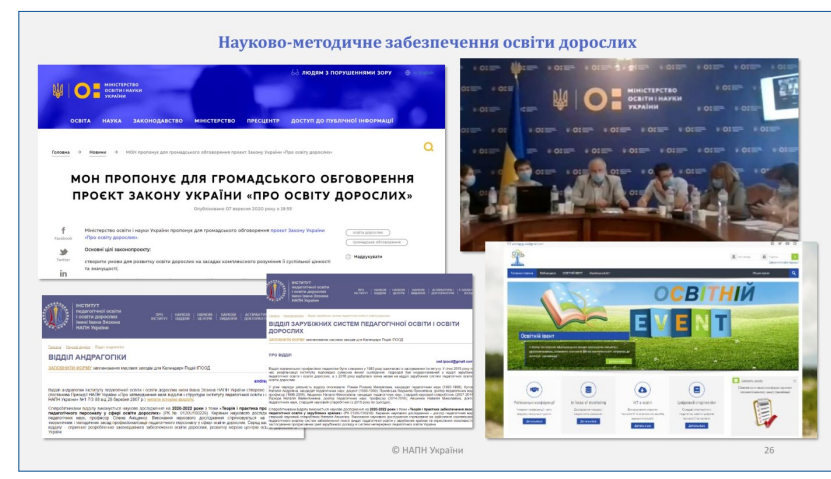

ність андрагога», освітню платформу «Профосвіта» як інноваційне навчально-цифрове середовище для безперервного професійного розвитку фахівців через формальну, неформальну та інформальну освіту.

9. Розроблено теорію і методики психологічної підтримки людини в умовах складних соціальних обставин, зокрема у ситуаціях гібридної війни, вимушеної міграції переселенців, соціальних і економічних трансформацій перехідного суспільства; концепції захисної поведінки групи в умовах колективної травми і групових інформаційних травм.

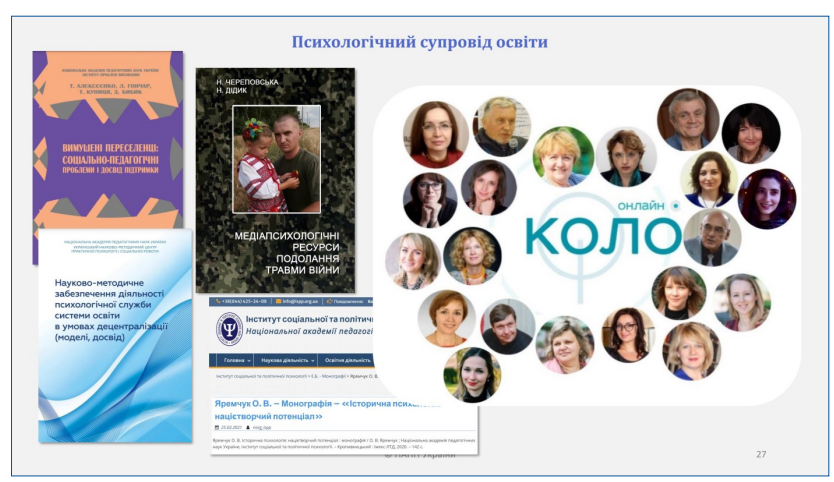

10. Теоретично обґрунтовано стратегію розвитку психологічної служби системи освіти в умовах децентралізації, запропоновані моделі управління і науково-методичного забезпечення служби на рівні «заклад освіти - територіальна громада», «територіальна громада - район», «район - область».

у звітному році підвищено рівень наукових друкованих (39) та електронних (10) періодичних видань НАПН України у контексті європейських ініціатив відкритої науки, відкритих цитувань та анотацій. До категорії «А» і «Б» віднесено 29 (60 \%) найменувань наукової періодики. Більшість (86\%) друкованих і електронних періодичних видань публікують статті різними мовами, зокрема українською, англійською, польською, німецькою, французькою тощо. Чотири видання - лише англійською мовою, три - тільки українською.

Електронне видання - журнал «ннформаційні технології і засоби навчання» представлено в базі даних Web of Science Core Collection, має категорію «А», за даними Бібліометрики української науки входить до переліку топ-10 періодичних видань України. У 2020 р. його переглядали майже 1 млн раз понад 26 тис. користувачів зі 193 країн світу (найбільше з України, США, Японії, Сполученого Королівства, Німеччини, Іспанії). 


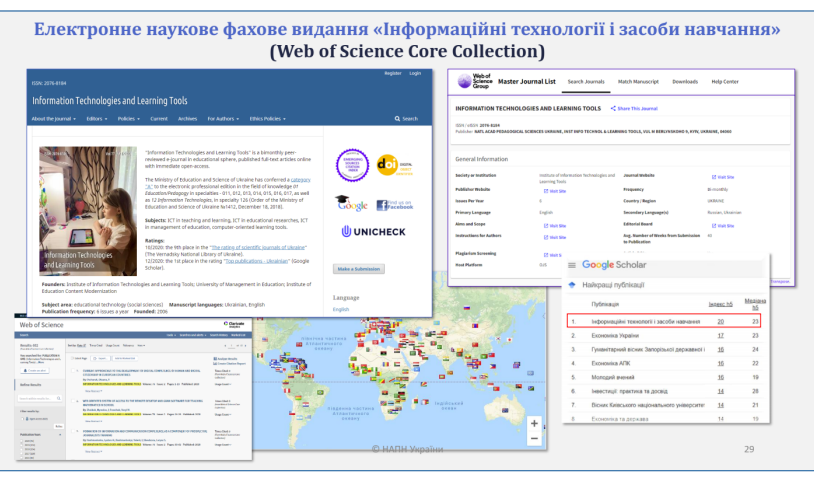

У НАПН України створено сучасну Електронну бібліотеку, у якій розміщено праці за результатами наукових досліджень вчених академії. У бібліотеці представлено 23 тис. повнотекстових ресурсів, з них $99 \%$ у вільному доступі. Вони завантажувалися 7,2 млн разів, з них 2,5 млн - у 2020 р., що істотно більше порівняно з попереднім роком. Кількість користувачів бібліотеки становила 67 тис. із 146 країн.

Успішно функціонує профіль НАПН України у Scopus.

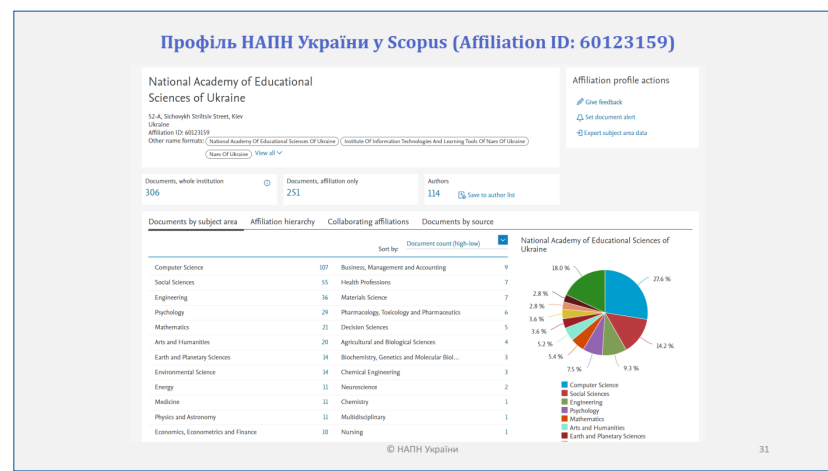

У рейтингу Бібліометрики української науки 11 підвідомчих установ НАПН України посідають місця, починаючи із 7 місця, цього рейтингу.

НАПН України посилила співпрацю з Комітетом Верховної Ради України з питань освіти, науки та інновацій, Міністерством освіти і науки України, Національним агентством забезпечення якості вищої освіти, Державною службою якості освіти, Національним агентством кваліфікацій, Національною академією наук України та національними галузевими академіями наук, закладами освіти всіх рівнів, іншими міністерствами і відомствами тощо. Завершено виконання Програми спільної діяльності МОН та НАПН України на 2017-2020 рр. та підписана нова Програма на 2021-2023 рр. Розпочато виконання Програми спільної діяльності НАН і НАПН України на 20202022 рр. тощо.

Вчені НАПН України систематично проводять незалежну наукову експертизу. Щороку подаються експертні висновки до понад 90 законодавчих, нормативно-правових актів, державних рішень i програм, освітніх інновацій та інформаційноаналітичних матеріалів, до понад 900 рукописів видавничої продукції, до понад 120 одиниць навчальної літератури, засобів навчання та навчального обладнання для закладів дошкільної, початкової, базової, профільної і середньої освіти, а також до понад 220 дисертацій і 180 авторефератів. Більше 130 провідних учених НАПН України брали участь у діяльності експертних, акредитаційних, робочих груп і комісій, агентств, програмних комітетів.

Вчені НАПН України провадять експериментальну діяльність у понад 1,4 тис. закладів освіти України. Більшість закладів (836), які беруть участь у всеукраїнських експериментах, затверджено наказами МОН України.

У НАПН України забезпечено підготовку здобувачів наукових ступенів доктора філософії та доктора наук через аспірантуру та докторантуру у галузях знань «01 Освіта / Педагогіка», «05 Соціальні та поведінкові науки», "23 Соціальна робота», «28 Публічне управління та адміністрування» у межах 65 наукових шкіл вчених академії. У 2020 р. досягнуто зростання ефективності аспірантури і докторантури. До роботи Міжвідомчої ради з координації досліджень у галузі освіти, педагогіки і психології, а також атестації у 14 спеціалізованих вчених радах залучено понад 80 провідних вчених України.

В Університеті менеджменту освіти та двох наукових установах підвищено кваліфікацію 8 тис. керівних, науково-педагогічних і педагогічних працівників освіти, що на 2 тис. більше, ніж у 2019 р.

У НАПН України здійснюється міжнародна діяльність шляхом: участі у майже 40 міжнародних освітніх і наукових проєктах і програмах Американських рад з міжнародної освіти, Британської ради в Україні, Еразмус+ Європейського Союзу, Європейського фонду підготовки, Представництва ООН в Україні, Представництва DVV International (Інституту міжнародного співробітництва Німецької асоціації народних університетів) в Україні, Ради Європи, Світового банку, ЮНЕСКО, ЮНІСЕФ; наукової співпраці з науковими установами і закладами освіти світу; провадження експертної діяльності в рамках міжнародних організацій; проведення міжнародних науково-практичних заходів; підвищення професійного розвитку та стажування вчених НАПН України. 
На $16 \%$ збільшилася кількість вчених НАПН України, які $є$ членами понад 50 міжнародних організацій, та на 19 \% зросла кількість міжнародних науково-практичних заходів, що проведені спільно із зарубіжними партнерами. На $9 \%$ зросла кількість вчених академії, які виїжджали за кордон з метою стажування, навчання, підвищення кваліфікації, викладання, досліджень.

НАПН України $\epsilon$ активним організатором чотирьох щорічних міжнародних виставок 3 питань освіти, а також близько 200 інших науковопрактичних масових заходів.

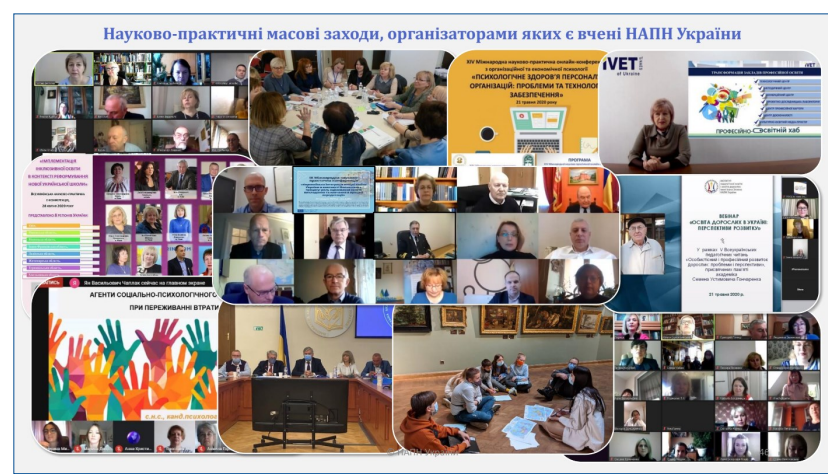

В академії збільшилися на 8,5 \% надходження за спеціальним фондом бюджету.

До нерозв'язаних проблем слід, як і раніше, віднести:

1.Хронічне недофінансування академії 3 огляду на складність і масштабність завдань та об'єктивно незначні можливості комерціалізації результатів діяльності в освітянській сфері.

2. Неконкурентоспроможність заробітної плати. Середньомісячна заробітна плата на повну ставку працівників за загальним фондом у 2020 р. була майже удвічі менша, а наукових працівників в 1,7 раза менша за середню заробітну плату в м. Києві.

3. Кількаразове зниження прийому в аспірантуру і докторантуру через брак коштів, що не сприяє омолодженню наукових колективів.

4. Дефіцит фінансових можливостей для участі вчених, аспірантів і докторантів у повноцінній міжнародній науковій діяльності, закордонних конференціях, стажуваннях, публікаціях тощо.

5. Обмежені можливості в оновленні дослідницького обладнання.

Перспективи розвитку НАПН України ми пов'язуємо з об'єктивно затребуваною потребою іï роботи для розвитку освітньої сфери. Це вимагає певних змін у нашій діяльності.

Попри те, що результати атестації наукових установ НАПН України виявилися досить позитив-

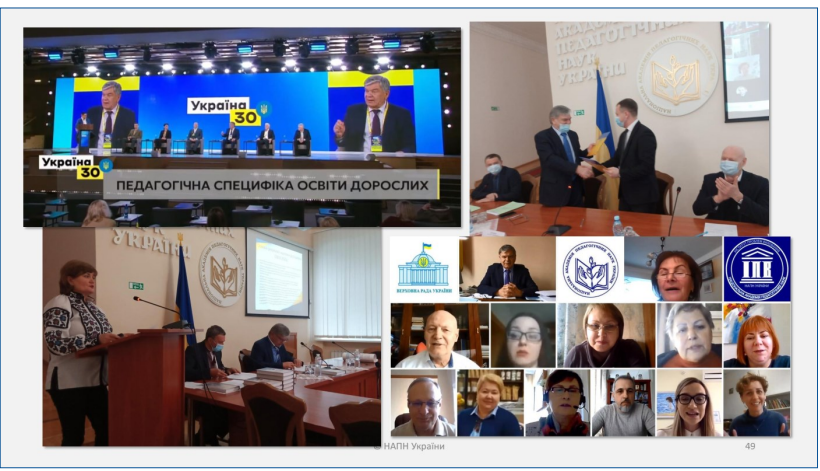

ними, академія останнім часом веде постійний діалог і співпрацює з МОН України щодо реформування НАПН України з метою подальшого підвищення її ефективності.

У протоколі Наукового комітету Національної Ради України з питань розвитку науки і технологій від 3 липня 2020 р. висловлена думка про «необхідність докорінної реорганізації» НАПН України. Ми готові розглянути на загальних зборах можливість такої реорганізації і прийняти відповідні рішення. Скажімо, про реорганізацію в Національну академію освіти України або Національну академію освітніх наук України.

Не перейменування, а саме реорганізацію.

Це зумовлено рядом об'єктивних причин. Передусім, що об'єктом досліджень все більше стає вся освіта як система в сукупності усіх їі аспектів, де педагогіка $є$ лише одним із важливих сегментів. Окрім педагогічних $€$ проблеми економіки, управління освітою, їі цифровізації, побудови оптимальної мережі закладів освіти, європейської інтеграції, взаємозв'язку із роботодавцями та інші.

у таку академію легше було б, скажімо, залучити не тільки доктора педагогічних наук, який колись закінчив фізичний факультет i вважається фахівцем із викладання фізики, а й доктора фізико-математичних наук, який добре обізнаний із сучасною фізикою і має своє бачення щодо змісту і методів викладання цього предмету.

Реорганізація дозволила б також провести кардинальні структурні зміни в академії, звільнитися від неефективно працюючих науковців і окремих підрозділів. I зробити роботу академії більш результативною.

Академії освіти існують в багатьох країнах від США, де вона $є$ однією із п'яти національних академій, до Російської Федерації, де функціонує Российская академия образования, яка, до речі, тридцять років назад стала правонаступницею Академії саме педагогічних наук. 
Ми хотіли 6 дізнатися про позицію шановних членів Наукового комітету.

Національна академія педагогічних наук України і надалі буде зосереджувати всі зусилля на гідному науковому і методичному супроводі розвитку освіти країни з тим, щоб вона стала дійсно сучасною і ефективною та забезпечила динамічний прогрес нашої країни.

\section{СПИСОК ВИКОРИСТАНИХ ДЖЕРЕЛ}

Березівська, Л.Д. (2021). Діяльність Державної науковопедагогічної бібліотеки України імені В.О. Сухомлинського щодо розвитку сухомлиністики в освітньо-науковому просторі: досвід і перспективи. Вісник Національної академії педагогічних наук України, 3(1). https://doi.org/10.37472/2707305X-2021-3-1-2-5

Биков, В.Ю. (2021). Формування компетентностей учасників освітнього процесу на основі хмаро орієнтованих інформаційно-освітніх систем. Вісник Національної академії педагогічних наук України, 3(1). https://doi.org/10.37472/2707-305X-2021-3-1-2-3

Довгий, С.О., \& Гальченко, М.С. (2020). Про співпрацю Інституту обдарованої дитини НАПН України і Малої академії наук України щодо запровадження спеціалізованої освіти наукового спрямування. Вісник Начіональної академії педагогічних наук України, 2(1). https://doi.org/10.37472/2707-305X2020-2-1-2-4

Драч, І.І., Калашнікова, С.А., Луговий, В.І., Слюсаренко, О.М., \& Таланова, Ж.В. (2020). Орієнтація керівника університету на результативний розвиток закладу. Вісник Національної академії педагогічних наук України, 2(2). https://doi.org/10.37472/2707-305X2020-2-2-11-7

Електронна бібліотека НАПН України. (n.d.). Головна. https://lib.iitta.gov.ua/

Засенко, В.В. (2020). Про наукову і науковоорганізаційну діяльність Інституту спеціальної педагогіки і психології імені Миколи Ярмаченка НАПН України за 2016-2020 рр. та перспективи його розвитку. Вісник Начіональної академії педагогічних наук України, 2(2). https:// doi.org/10.37472/2707-305X-2020-2-2-2-4

Інститут педагогіки НАПН України. (n.d.). Електронна бібліотека. Підручники. http://undip.org.ua/news/ library/pidruchniki.php

Кириченко, М.О. (2020). Про наукову і науковометодичну діяльність Державного закладу вищої освіти «Університет менеджменту освіти» в умовах децентралізації управління освітою. Вісник Національної академії педагогічних наук України, 2(2). https://doi.org/10.37472/2707-305X-2020-2-2-2-6

Кремень, В.Г. (2020). Про Програму спільної діяльності Національної академії наук України та Національної академії педагогічних наук України на 20202022 роки. Вісник Національної академії педагогічних наук України, 2(1). https://doi.org/10.37472/2707305X-2020-2-1-2-3

Кремень, В.Г. (2021). Законодавче забезпечення і шляхи реформування Національної академії наук та національних галузевих академій наук. Вісник
Національної академії педагогічних наук України, 3(1). https://doi.org/10.37472/2707-305X-2021-3-1-15-1

Кремень, В.Г. (2021). Партнерський форум «Освіта України 2021: стратегічні цілі та пріоритетні напрями». Вісник Національної академії педагогічних наук України, 3(1). https://doi.org/10.37472/2707305X-2021-3-1-3-1

Кремень, В.Г. (2021). Про Програму спільної діяльності Міністерства освіти і науки України та Національної академії педагогічних наук України на 2021-2023 роки. Вісник Національної академії педагогічних наук України, 3(1). https://doi.org/10.37472/2707305X-2021-3-1-11-1

Кремень, В.Г. (ред.). (2021). Звіт про діяльність Національної академії педагогічних наук України у 2020 p. Київ: НАПН України. https://doi.org/10.37472/ zvit2020

Кремень, В.Г. (2021). Про діяльність Національної академії педагогічних наук України у 2020 році та завдання на 2021 рік. Вісник Національної академії педагогічних наук України, 3(1). https:// doi.org/10.37472/2707-305X-2021-3-1-1-1

Кремень, В.Г. (2021). Педагогічна специфіка освіти дорослих. Вісник Національної академії педагогічних наук України, 3(1). https://doi.org/10.37472/2707305X-2021-3-1-3-6

Кремень, В.Г., Луговий, В.І., \& Саух, П.Ю. (2020). Освіта і наука - основа інноваційного людського розвитку. Вісник Національної академії педагогічних наук України, 2(2). https://doi.org/10.37472/2707-305X2020-2-2-14-3

Кремень, В.Г., Луговий, В.І., Топузов, О.М., Регейло, І.Ю., \& Базелюк, Н.В. (2020). Про виконання Програми спільної діяльності Міністерства освіти і науки України та Національної академії педагогічних наук України на 2017-2020 роки. Вісник Національної академії педагогічних наук України, 2(2). https://doi.org/10.37472/2707-305X-2020-2-2-2-3

Кремень, В.Г., Луговий, В.І., Топузов, О.М., Регейло, І.Ю., \& Базелюк, Н.В. (2020). Про виконання у 2020 р. Програми спільної діяльності Національної академії наук України та Національної академії педагогічних наук України на 2020-2022 роки. Вісник Національної академії педагогічних наук України, 2(2). https://doi.org/10.37472/2707-305X2020-2-2-2-5

Лук'янова, Л.Б. (2020). Законодавче забезпечення освіти дорослих в Україні: сучасний стан та перспективи розвитку. Вісник Національної академії педагогічних наук України, 2(2). https:// doi.org/10.37472/2707-305X-2020-2-2-1-2

Луговий, В.І. (2020). Проблема освітньої якості в стратегії розвитку вищої освіти в Україні. Вісник Національної академії педагогічних наук України, 2(2). https://doi.org/10.37472/2707-305X-2020-2-2-11-1

Луговий, В.І., Регейло, І.Ю., \& Гудим, І.М. (2021). Про результати виконання у 2020 році прикладних наукових досліджень для підтримки молодих вчених. Вісник Національної академії педагогічних наук України, 3(1). https://doi.org/10.37472/2707305X-2021-3-1-2-1

Луговий, В.І., Регейло, І.Ю., \& Гудим, І.М. (2021). Про співпрацю Національної академії педагогічних наук України з комітетами Верховної Ради України у 
2020 р. Вісник Національної академії педагогічних наук України, 3(1). https://doi.org/10.37472/2707305X-2021-3-1-16-2

Ляшенко, О.І. (2020). Презентація проєкту Державного стандарту базової середньої освіти: чим новий стандарт відрізняється від попередніх? Вісник Національної академії педагогічних наук України, 2(2). https://doi.org/10.37472/2707-305X-2020-2-2-11-5

Міністерство освіти і науки України. (2021). Державна атестація наукових установ. https://mon.gov.ua/ ua/nauka/nauka/derzhavna-atestaciya-naukovih-ustanov

Наукова продукція Національної академії педагогічних наук України, рекомендована до впровадження (2020р.) : Збірник анотованого переліку наукової продукції. Київ: НАПН України. https:// bit.ly/3eq54d5

Національна академія педагогічних наук України. (n.d.). Головна. http://naps.gov.ua/

Національна академія педагогічних наук України. (2021). Інформація Національної академії педагогічних наук України про використання коштів Державного бюджету України за 2020 рік. https://bit.ly/3еinBYY

Ничкало, Н.Г. (2020). Наукове забезпечення розвитку освіти дорослих в Україні. Вісник Начіональної академії педагогічних наук України, 2(2). https:// doi.org/10.37472/2707-305X-2020-2-2-1-1

Онопрієнко, О.В. (2020). Про діяльність відділу початкової освіти Інституту педагогіки НАПН України щодо реалізації Державного стандарту початкової освіти. Вісник Начіональної академії педагогічних наук України, 2(1). https:// doi.org/10.37472/2707-305X-2020-2-1-8-2

Панок, В.Г. (2020). Концепція психологічного супроводу освітніх реформ у діяльності психологічної служби. Вісник Начіональної академії педагогічних наук України, 2(1). https://doi.org/10.37472/2707305X-2020-2-1-9-1

Президент України. (1992, 4 березня). Про заснування Академії педагогічних наук України (124). https:// zakon.rada.gov.ua/laws/show/124/92

Президент України. (2010, 24 лютого). Про надання Академії педагогічних наук України статусу національної (259/2010). https://zakon.rada.gov.ua/ laws/show/259/2010

Сисоєва, С.О., \& Рейпольська, О.Д. (2020). Концепція освіти дітей раннього та дошкільного віку: новий погляд. Вісник Начіональної академії педагогічних наук України, 2(1). https://doi.org/10.37472/2707305X-2020-2-1-2-2

Слюсаревський, М.М. (2020). «Онлайн-коло»: досвід психологічної підтримки і допомоги населенню під час пандемії Covid-19. Вісник Національної академії педагогічних наук України, 2(1). https:// doi.org/10.37472/2707-305X-2020-2-1-7-8

Радкевич, В.О. (2021). Наукова платформа професійної освіти: сталий розвиток. Вісник Національної академії педагогічних наук України, 3(1). https:// doi.org/10.37472/2707-305X-2021-3-1-17-1

\section{NATIONAL ACADEMY OF EDUCATIONAL SCIENCES OF UKRAINE REPORT ON THE STATE OF USING THE FUNDS FOR RESEARCH ACTIVITIES AND THE RESULTS RECEIVED IN 2020 \\ Scientific Report at the Meeting of the National Council of Ukraine for Science and Technology Development Working Group, June 16, 2021, Kyiv, Ukraine \\ Vasyl Kremen \\ DSc in Philosophy, Professor, Full Member (Academician) of NAS of Ukraine and NAES of Ukraine, President, National Academy of Educational Sciences of Ukraine, Kyiv, Ukraine}

Abstract. The results of research activities of the National Academy of Educational Sciences of Ukraine in 2020, its subordinated institutions, human resource development are enlightened in the report. The most important achievements of the NAES of Ukraine researchers in the scientific and methodological support of preschool, complete general secondary, vocational, professional pre-higher, higher and adult education, education of children with various developmental disabilities and transition to inclusive education, education digitalization and distance learning, psychological support for personality development, in particular in difficult social circumstances, development of the education system psychological service in the process of decentralization. The NAES of Ukraine researchers' prominent achievements in the National Research Fund of Ukraine and international grant projects are given. The main indicators of the NAES of Ukraine activities in 2020 concerning scientific publications, i.e. significant increase of the number of works indexed in the Web of Science and Scopus databases, uploading and using the resource of the Digital Library of NAES of Ukraine, increasing the quality of scientific journals, cooperation with public authorities, organizations, institutions, expansion of expert and experimental activities, PhD and DSc students' preparation, specialized research councils activities, work with young scientists, international collaboration, scientific and practical public events, etc. Attention is drawn to unresolved issues and development prospects are outlined. The capability of the NAES of Ukraine researchers to solve comprehensively current problems of education development and a human in it, conduct systematic and planned researches in the sphere of education, pedagogy and psychology is emphasized.

Keywords: National Academy of Educational Sciences of Ukraine; research activities; Ukrainian education; pedagogy; psychology; scientific and methodological support; innovative person development; human potential. 